\title{
Preface
}

Social scientists, like the general public, have shown a great interest in the prison but have almost completely ignored the jail. Since John Howard's historic report on English jails, The State of the Prisons in England and Wales (1777), there have been perhaps a dozen other reports (most of which are listed in the bibliography), whereas there are hundreds of studies on the prison. The opposite focus is more appropriate for several reasons. First, many more people pass through the jail. The estimates range from 3 to 7 million a year in the United States, and this is at least thirty times the number handled by all state and federal prisons. Second, when persons are arrested, the most critical decisions about their future freedom are made while they are either in jail or attached to it by a bail bond. These decisions, like the decision to arrest, are often highly discretionary and raise disturbing questions about the whole criminal justice system. Third, the experiences prisoners endure while passing through the jail often drastically influence their lives. Finally, the jail, not the prison, imposes the cruelest form of punishment in the United States.

Although recognizing the jail was more important, I too concentrated on the prison for many years. In the mid-1970s I made one attempt to begin a study of the the jail after Richard Hongisto, a personal friend, was elected sheriff of San Francisco and agreed to give me full access to the three jails he administered-no small matter, because social scientists have had more difficulty approaching the jail than the prison. However, the prison issue continued to absorb me, and I did 
not take up the offer. Finally, in 1979, after finishing a book on prisons, I again resolved to study the jail. Though Hongisto had resigned and a less adventurous sheriff had been appointed to replace him, Hongisto had created a prisoner services program through which I was able to circulate in the San Francisco jails. Prisoner services attempts to fill jail prisoners' myriad needs: contact with families, lawyers, friends, and employers; removal of detainers from other jurisdictions; and recovery of personal property. (In the middle of my research Michael Hennessey, a former prisoner services lawyer, was elected sheriff of San Francisco and gave full support to my study.) In 1979 and 1980 I was a caseworker on the felony floors of the three San Francisco jails that hold pretrial detainees. Several times a day I visited the felony "tanks" (large cells holding a number of prisoners) to gather "requests for action," clarify the requests that had been forwarded to the prisoner services' offices, and tell prisoners the response to their requests. On these visits I soon moved from outside the tank to inside where I engaged in many informal conversations with prisoners. Also I interviewed selected prisoners in private.

After observing in the jail for a year, I left prisoner services and for several months accompanied public defenders to their various hearings. During this period I also interviewed and accompanied persons working for the San Francisco OR project, a program for the release of prisoners on their own recognizance.

By spring 1981 I had formed a particularly significant impression: the vast majority of prisoners in the jail were very different from the popular conception of a criminal. I needed to strengthen this impression with firmer data, so I randomly selected 100 persons charged with felonies and 100 charged with misdemeanors from the booking records at the jail. With Nancy Strachan, a research assistant, I interviewed the felony arrestees and followed both samples' cases through the jail and the court records until they were resolved. (A more complete description of this phase of the study appears at the beginning of Chapter 2.)

Although I studied the San Francisco jails, my findings may be relevant to jails in general. During my work I was a part of a broader study of three county jails-San Francisco, Yolo, and Los Angeles. I not only consulted the quantitative data gathered in these studies, but I made several visits to the Yolo County jails and the main county jail in Los Angeles. Moreover, having been a prisoner in eight different city 
and county jails for periods up to 120 days, I have firsthand experience with jails. Finally, I have drawn from the literature on jails to verify, compare, and correct my own findings.

I selected San Francisco's jails because of their availability, but they were also appropriate to the study. The San Francisco County jails represent a type of jail, the "big-city" jail. San Francisco is near the median in age, decrepitude, range of facilities, level of deprivation, and overall harshness imposed on prisoners. Its only uniqueness derives from ten years of very active reform-minded sheriffs since 1972 and the differences they effectuated. Moreover, there are powerful contextual forces that produce similarities in jails, particularly in big-city jails.

I ignored women in jail primarily because I based most of the study on my own participation, spending much time at the tanks and other locations in the men's jail. I did not feel that it would be appropriate to attempt to do this in the women's jail. (I also doubt that I would have been allowed to.) Besides, women are a notably different jail population and require a separate study.

Most of my attention was on pretrial prisoners and the pretrial processes. Though they constitute only about half of the prisoners, pretrial detainees are in many respects the more significant ones. Historically, jails have been mainly places to hold persons for trial. The sentencing function was added relatively recently and more as an adjacent development to the penitentiaries, the first major prisons used in the United States for punishment. The pretrial phase remains the most controversial (because of the judicial theory of innocence until conviction), most relevant to the judicial processes, and most consequential to prisoners. Therefore, I give much less attention to the sentencing phase.

My critical discovery was that instead of "criminals," the jail receives and confines mostly detached and disreputable persons who are arrested more because they are offensive than because they have committed crimes. Moreover, I learned that the primary purpose of the jail is to manage these persons, whom I finally decided to call the rabble. I also discovered that in managing the rabble by arresting them and holding them in jail, society inadivertently increases their number and holds people in a rabble status.

These ideas are the focus of the book. Chapter 1 examines the purpose of the jail as rabble management by presenting a brief history of the jail in England and America. Chapter 2 shows who goes to jail and 


\section{XXVi PREFACE}

what they go there for. Chapters 3, 4, 5, and 6 describe in detail what actually happens to people who are arrested and jailed and explores some of the frequent personal and social consequences of that experience. In Chapter 7, I discuss in broad sociological terms the problems related to reforming the jail. 